\title{
When Was Judicial Self-Restraint?
}

\author{
Aziz Z. Huq*
}

This Essay responds to Judge Posner's Jorde Symposium Essay The Rise and Fall of Judicial Restraint by analyzing the question of when, if ever, has judicial self-restraint thrived in the federal courts. Its central aim is to shed historicizing light on the trajectory of judicial activism by imaginatively rifling through an array of canonical and somewhat-less-than-canonical empirical identification strategies. Two conclusions follow from the inquiry. First, I find that the available data on the historical trajectory of judicial restraint are surprisingly poor, and it is necessary to offer any judgment about the historical path of judicial activism with great caution. Second, although the empirical record is fragmentary, some common points emerge from the use of divergent methodologies. Specifically, I suggest that the temporal domain of judicial activism should be expanded further back into American history than generally assumed. It was in the immediate aftermath of the Civil War that judicial behavior changed in a consequential way. That postbellum period has largely dropped out of the study of judicial activism, but should receive more attention than it currently does.

Introduction.

I. Gauging the "When" of Judicial Activism ................................................ 583

A. Indications of Postbellum Judicial Activism .............................. 584

B. Limitations in the Data............................................................ 588

C. Suggestions to Clarify the Historical Role of Judicial Activism .592

II. Recasting the History of Judicial Activism ............................................ 597

A. The Warren Court ............................................................................ 597

Copyright (C) 2012 California Law Review, Inc. California Law Review, Inc. (CLR) is a California nonprofit corporation. CLR and the authors are solely responsible for the content of their publications.

* Assistant Professor of Law, University of Chicago Law School. My thanks to Jane Dailey, Hon. Frank Easterbrook, Dennis Hutchinson, Alison LaCroix, Justin Levitt, Hon. Richard Posner, Adam Samaha, and Geof Stone for insightful comments, conversations, and criticisms. I am also very grateful to Eileen Ho for research assistance and to the editors of the California Law Review for their excellent suggestions and editorial work. Finally, I am pleased to acknowledge the support of the Frank Cicero, Jr. Faculty Fund. All errors are mine alone. 
B. The Postbellum Period 599

C. Public Discussion of Judicial Activism 603 Conclusion 605

\section{INTRODUCTION}

Legal scholarship abounds with unadorned juxtapositions of the terms “judicial activism” and "judicial self-restraint.” Yet, as Judge Richard Posner has long emphasized, that terminological antinomy is not self-explanatory. It is rather employed in two quite distinct senses to refer to two quite different underlying phenomena. ${ }^{1}$ First, the sibling terms are wielded in normative scholarship as a means of commenting on the appropriate role of a judiciary that exercises a constitutional negative in the context of a democratic polity. Second, the terms are also invoked in descriptive accounts of how judges behave when resolving potential conflicts between laws and the United States Constitution (e.g., to describe the rate of invalidation of state and federal statutes). Many academic treatments elide their discussions of the normative and the descriptive, or are reticent about where description ends and the normative begins. The catalyst for this Essay, Judge Posner's Essay The Rise and Fall of Judicial Restraint, makes no such category error. It speaks first to the trajectory of normative scholarship through an intellectual history of Thayerian deference. ${ }^{2}$ It then addresses separately the descriptive question of how judicial behavior has changed over time through a lively dissection of how "Thayerian theory [works] ... in the courts." ${ }^{3}$ On neither front, Judge Posner concludes with manifest regret, does self-restraint thrive today.

This Essay responds to Judge Posner's insightful Essay by addressing in more detail some of the historical questions raised by descriptive usage of the judicial activism/restraint pairing. Specifically, I ask here when, if ever, judicial self-restraint thrived in the federal courts: If today is postlapsarian, when was the Eden of restraint? This descriptive question is not addressed extensively by Judge Posner's Essay. Yet his interrogation of Thayer's influence, his spirited defense of pragmatic adjudication, and his empirical exploration of activism on the contemporary bench fairly implicate the historical question of just when self-restraint was in the ascendant. By extending the study of judicial activism back before the opening of the twentieth century, moreover, Judge Posner has flagged the important related question of how contemporary debates about

1. The distinction is drawn in Richard A. Posner, The Supreme Court 2004 Term, Foreword: A Political Court, 119 HARV. L. REV. 31, 32-34 (2005) [hereinafter Posner, Foreword].

2. Richard A. Posner, The Rise and Fall of Judicial Self-Restraint, 100 CALIF. L. REV. 519 (2012) [hereinafter Posner, Rise and Fall]. By "Thayerian deference” I mean the theory associated with James Bradley Thayer that federal courts "can only disregard [an] Act when those who have the right to make laws have not merely made a mistake, but have made a very clear one.” James Bradley Thayer, The Origin and Scope of the American Doctrine of Constitutional Law, 7 HARV. L. REV. 129, 144 (1983).

3. See, e.g., Posner, Rise and Fall, supra note 2, at 546. 
"judicial activism" should be situated in a larger historical account of American judicial and political development.

Following Judge Posner, I define judicial activism for present purposes to measure the frequency with which courts declare "legislative or executive action unconstitutional." ${ }^{4}$ I therefore focus here on a relatively narrow species of judicial behavior of particular concern in a political system that is otherwise facially committed to democratic norms. My central aim is to shed some historicizing light on the trajectory of judicial activism so defined by imaginatively rifling through an array of canonical and somewhat-less-thancanonical empirical identification strategies. ${ }^{5}$ I draw two conclusions, which, to my embarrassment, are partly at war with each other.

First, I suggest that the available data on the historical trajectory of judicial activism/restraint are surprisingly poor. Notwithstanding some recent empirical analyses, ${ }^{6}$ current understandings of the federal judiciary's historical movement along a judicial self-restraint/activism spectrum, and in particular the question of when any historical era of restraint ended, remain inadequately explored. Many of the recent and canonical studies have serious methodological and conceptual problems. ${ }^{7}$ Alternative and novel means of investigating the historical question have not been exploited. As a result, our inarticulate but shared intuitions about the historical trajectory of judicial activism may rest on unrepresentative anecdotes and incomplete data. At the very least, it seems most appropriate now to offer judgments about the historical path of judicial activism with great caution and in the expectation of

4. Id. at 521. For a slightly different definition, see RICHARD A. POSNER, HOW JUDGES THINK 287 (2008) [hereinafter POSNER, HOW JUDGES THINK] (defining the activism/restraint spectrum according to whether a decision "expands the Court's authority relative to that of the other branches of government"). This is not the only sensible way in which the term judicial activism could be operationalized. For an alternative definition of activism that leverages the differences between legal standards of review, see Corey Rayburn Yung, Flexing Judicial Muscle: An Empirical Study of Judicial Activism in the Federal Courts, 105 Nw. U. L. REV. 1, 19-22 (2011). One might alternatively reject entirely the utility of the term. For example, one of Judge Posner's colleagues on the Seventh Circuit Court of Appeals, Judge Easterbrook, has argued for the term's "abolition" because of its analytic vacuity and its routine deployment as a mere label of normative or political opprobrium. Frank Easterbrook, Do Liberals and Conservatives Differ in Judicial Activism?, 73 U. COLO. L. REV 1401, 1402 (2002). I agree with Judge Easterbrook's evaluation of how the term is used in current political discourse. Moreover, I do not mean to suggest that any simple political lessons can be drawn from the historicizing enterprise here. To the contrary, a richer understanding of historical trends ought to puncture the cavalier certainties of contemporary activism's critics by showing how varied "activism" has been. I labor under no illusion, however, of landing a fatal blow on the rhetoric of activism here, alas.

5. My strategy here is therefore distinct from the more historical and impressionistic approach taken in BARRY FRIEDMAN, THE WILL OF THE PEOPLE: HOW PUBLIC OPINION HAS INFLUENCED THE SuPREME COURT AND SHAPED THE MEANING OF THE CONSTITUTION (2009) (chronicling public attitudes toward the Supreme Court throughout American history).

6. See, e.g., William M. Landes \& Richard A. Posner, Rational Judicial Behavior: A Statistical Study, 1 J. LEGAL ANALYSIS 775 (2009).

7. See infra Part I.B. 
further historical and empirical work that sweeps away today's pieties. I hope the conclusions in this Essay are taken in that humble and corrigible spirit.

Second, although the empirical record is fragmentary, some noteworthy commonalities emerge from the divergent methodologies. In the second Part of the Essay, I bring out those commonalities as a way of prompting reconsideration of currently shared assumptions about the "when" of judicial activism. Specifically, I intimate that the temporal domain of activism should be expanded further back into American history than is generally assumed. To see why, consider one piece of folk wisdom among lawyers and legal scholars that is recapitulated in The Rise and Fall of Judicial Restraint: the "judicial demise of the Thayerian theory [i.e., self-restraint on the bench]... is attributable to the exuberant activism of the Warren Court...." ${ }^{8}$ In other words, our current age of rampant, even lurid, activism on the bench is sharply separated from a longer period of more democratic, more modest, and more appropriate judicial behavior. According to the conventional wisdom, the continuity-breaking spike of activism arrived during the Warren Court, which lasted from 1953 to $1969 .^{9}$

In what follows, I argue that although the partial and fragmentary data assembled here do suggest that the Warren Court was one of the discontinuities in the Supreme Court's behavior, the data also suggest that the Warren Court was neither the origin of activism nor the terminus of restraint. I hope this is not really news. It has long been known that well before the Warren Court, during the so-called Lochner era of the 1890s through to the 1930s, federal courts also fairly frequently invalidated both state and federal laws on constitutional grounds that have since been repudiated. ${ }^{10}$ These earlier decisions were so contentious that President Franklin Roosevelt famously proposed a controversial court-packing plan to change the outcomes of Supreme Court review. ${ }^{11}$ So the idea that judicial activism might predate Earl Warren should hardly be startling.

8. Posner, Rise and Fall, supra note 2, at 546.

9. The conventional arc is rehearsed in the first and last chapter headings of Lucas Powe's recent history of the Court-“Very Modest Beginnings” and "An Imperial Court.” LuCAS A. PowE, JR., THE SUPREME COURT AND THE AMERICAN ELITE 1789-2008, at 1, 312 (2009).

10. Lochner v. New York, 198 U.S. 45 (1905) (invalidating New York law that regulated bakers' working conditions); see Cass R. Sunstein, Lochner's Legacy, 87 COLUM. L. REV. 873, 874 (1987) ("The received wisdom is that Lochner was wrong because it involved ‘judicial activism': an illegitimate intrusion by the courts into a realm properly reserved to the political branches of government."). Lochner is a synecdoche for a line of cases in which the federal courts of the Progressive Era invalidated redistributive economic legislation. In another account of judicial activism, Thomas Keck traces it back to 1937 and the end of the Lochner line of cases. See THOMAS M. KECK, THE MOst ACTIVIST Supreme COURT IN History: THE ROAD OF MODERN JudiCiAL CONSERVATIVISM 17-19 (2004).

11. See JeFF SHESOL, SUPREME POWER: FRANKLin ROOSEVElT VS. THE SUPREME COURT 291-306 (2010) (describing President Roosevelt's announcement of the plan and the hostile public response). 
Yet the Lochner era, no less than the Warren Court era, was not the opening salvo of judicial activism in American history. Rather, the data collated here point instead to the immediate aftermath of the Civil War and the Reconstruction period-some two to three decades prior to the Lochner era-as the pivotal moment at which judicial behavior changed in a consequential way. Simply put, before the Civil War, few state or federal statutes were invalidated by federal courts for constitutional reasons. After the Civil War, the pace of overt invalidations on constitutional grounds picked up dramatically. The fundamentally upward trajectory in the rate of activist decisions then continued, with only temporary setbacks, up through at least the end of the Rehnquist Court in 2005. Those seeking a culprit for the "fall” of judicial self-restraint are therefore well advised to look to the little-studied postbellum Court of the 1860s and 1870s, rather than the Warren Court or the Lochner era. Even others less intent on fixing blame for our current activist predicament should consider anew the legacy of that historical period, which has largely and unfortunately dropped out of the study of American constitutional law.

I.

\section{GAUGING THE “WHEN” OF JUDICIAL ACTIVISM}

It is increasingly common ground among historians that judicial review is older than Marbury. ${ }^{12}$ Even before the Constitution's 1788 ratification, colonial judges acted upon a felt "duty to decide in accord with the law of the land," including the Constitution. ${ }^{13}$ The new Supreme Court-the only federal tribunal mandated by Article III-began to inch toward a muscular stance on judicial review almost immediately under its second Chief Justice, Oliver Ellsworth. ${ }^{14}$ But when did that juridical possibility of statutory invalidation become quotidian judicial practice? At what moment in the history of the American federal courts was a quondam norm of restraint (if there ever was one) abandoned?

Many studies of judicial activism and self-restraint concentrate on only recent history in an effort to evaluate sitting and recent Justices going back to

12. Marbury v. Madison, 5 U.S. (1 Cranch) 137, 176 (1803) (marking the beginning of constitutional invalidation). The best account of the pre-Marbury roots of judicial review is PHILIP HAMBuRGER, LAW AND JudiCIAL DuTY 406-61 (2010) (collecting cases from New Jersey, New Hampshire, Rhode Island, and North Carolina). For another account that also traces judicial review back in time beyond the Revolution to "a longstanding English corporate practice under which a corporation's ordinances were reviewed for repugnancy to the laws of England," see Mary Sarah Bilder, The Corporate Origins of Judicial Review, 116 YALE L.J. 502, 504 (2006).

13. HAMBURGER, supra note 12, at 17.

14. Prior to Marbury, the Ellsworth Court signaled its willingness to rule on the constitutional validity of federal law. See Hylton v. United States, 3 U.S. (3 Dall.) 171 (1796) (upholding federal tax on carriages). The Court even invalidated as-applied some parts of a federal enactment. See Mossman v. Higginson, 4 U.S. (4 Dall.) 12 (1800) (holding that section 11 of the 1789 Judiciary Act could not be constitutionally read to extend to suits between two aliens). 
the New Deal. ${ }^{15}$ In part this focus is motivated by the simple fact that better data exist for more recent periods of judicial activity than for some older periods in time. By pushing back the inquiry to the late 1800s, Judge Posner raises the stakes and introduces larger historical questions: How has use of the judicial power to invalidate the legislated products of democratic assemblies been exercised since Congress first fashioned federal courts in 1789? Has judicial activism steadily waxed, even as judicial self-restraint has waned? Is there, in fact, a discernible rise, followed by a fall, in the quantity of judicial restraint, as Judge Posner's lecture title suggests? Indeed, is the path of judicial activism even linear, or is the history of judicial restraint in federal courts better characterized as cyclical? ${ }^{16}$

Answers to these interconnected inquiries are surprisingly elusive. There is no clearly dispositive empirical study of judicial activism, and, as I shall explain below, the one available semi-official source has recently been vigorously challenged by political scientists. ${ }^{17}$ The existing data rest on controversial and incompletely theorized assumptions. Potentially promising lines of empirical inquiry have gone unexplored. To collate what is known, this Part works through four ways in which the question "when was judicial selfrestraint?" might be approached. The first two are straightforward, and one can be described as almost canonical. But both leave many important empirical and conceptual questions unresolved. The shortfalls of standard inquiries imply there is more work to be done. I therefore offer two unorthodox takes on (something like) activism's historical pathway. These perspectives are offered in an adventurous spirit. Even if they are ultimately analytic dead ends, I hope they provoke new questions about our shared history quite beyond the support they provide to the larger conclusions drawn in the following Section.

\section{A. Indications of Postbellum Judicial Activism}

Consider first the semiofficial approach to counting the frequency of federal and state law invalidations. The Congressional Research Service of the Library of Congress (LOC) maintains the "canonical catalog[] of cases" in which the Supreme Court has invalidated a federal or state law. ${ }^{18}$ The LOC

15. See, e.g., STEFANIE A. LINDQUIST \& FrAnK B. CROss, MEASURING JUDICIAL ACTIVISM 49-52, 70-74 (2009) (separately addressing federal and state law invalidations). Much of Cross and Lindquist's work addresses the separate and separately important question of intrabench comparisons between Justices. See id. at 136; see also Yung, supra note 4, at 2 (looking at sitting courts of appeals judges).

16. See EVAN TSEn LEE, JUDICIAL RESTRAINT IN AMERICA, at ix (2011) ("In the last 100 or so years, the nation has oscillated between its commitment to judicial vindication of vested rights and its commitment to government by the people.”). Perhaps oddly, Lee claims to have identified "origins of judicial restraint doctrine in the Supreme Court" in his narrative survey of only a century of law. Id. at 195.

17. See infra text accompanying notes 24 to 28.

18. Keith E. Whittington, Judicial Review of Congress Before the Civil War, 97 GEO. L.J. 1257, 1261-62 (2009) [hereinafter Whittington, Judicial Review Before the Civil War]. I call the 
maintains separate lists of federal laws and state or municipal laws invalidated by the Court, and also a stand-alone list of state laws held preempted by federal laws. ${ }^{19}$ The latter, however, includes some cases in which the Court ousted a state law not merely based on a conflict with a federal law but also with a provision of the federal Constitution other than the Supremacy Clause. The LOC lists are current up to 2002.

The LOC does not provide an explanation for how it has coded cases. ${ }^{20}$ This makes conclusive interpretation of its data difficult. Nevertheless, the LOC lists provide at least a starting point for historical inquiry into judicial activism. It is possible to use them to identify the basic trajectory of judicial activism across time. Figure 1 illustrates the results of a manual count of all cases listed by the LOC as constitutional invalidations of a state or federal enactment between 1800 and 2000. I also have included in this count all of the preemption cases listed by the LOC in which the Court did not simply cite a federal statute or the Supremacy Clause but also cited a separate and distinct constitutional provision as a basis for its ruling. ${ }^{21}$ Figure 1 solely summarizes the LOC data; it reflects no judgment on my part about the LOC's selection criteria or other methodological questions. ${ }^{22}$

LOC's approach "semi-official" because, while a governmental body that is generally held in high esteem produces it, it has no formal or juridical status. It is not, that is, the federal government's standardized measure of judicial activism.

19. See Acts of Congress Held Unconstitutional in Whole or in Part by the Supreme Court of the United States, in Cong. ReSEARCH SeRV., S. Doc. No. 108-17, The Constitution OF THE UNITED STATES: ANALYSIS AND INTERPRETATION 2117 (2002), available at http://www.gpo.gov/ fdsys/pkg/GPO-CONAN-2002/pdf/GPO-CONAN-2002-10.pdf; State Constitutional and Statutory Provisions and Municipal Ordinances Held Unconstitutional or Held to Be Preempted by Federal Law 1789-2002, in CONG. RESEARCH SERV., supra, at 2161, available at http://origin.www.gpo.gov/ fdsys/pkg/GPO-CONAN-2002/pdf/GPO-CONAN-2002-11.pdf; see also LEE EPSTEIN ET AL., THE SUPREME COURT COMPENDIUM: DATA, DECISIONS, \& DEVELOPMENTS 176-207 (4th ed. 2006) (reporting federal and state laws invalidated by the Supreme Court between 1789 and 2005 based on data from the Congressional Research Service).

20. Coding concerns the protocols used by the compiler of the list for determining when to include and when not to include an item on the list. On the importance of rigorous coding, see R.M. LAWLESS ET AL., EMPIRICAL METHODS IN LAW 166-83 (2010).

21. The distinction between preemption cases and constitutional cases may strike some as artificial. After all, a preemption holding necessarily entails an application of the Supremacy Clause. But most preemption cases do not involve the unmediated application of judicial doctrine directly inferred from the Constitution and applied to a state statute-a federal law plays an intermediating role. Arguably, where Congress by enactment of a statute with preemptive effect has displaced a state law, the court enforcing that federal rule does not engage in "judicial activism" in any simple way because it has an imprimatur of congressional support. Of course, this account is too simple. It elides, for example, the possibility of judicial discretion as to the metes and bounds of preemptive effects. I do not control for that possibility here because of uncertainty as to the appropriate measure of judicial fidelity to congressional goals in the application of preemptive statutes.

22. The first step in the construction of Figure 1 was a manual count of cases listed by the LOC as involving the invalidation of a law, and an assignment of those cases to a decade according to the date reported in the U.S. Reporter. Examination of the LOC's preemption list, however, revealed cases in which the Court relied on constitutional grounds as well as statutory reasons. In any case listed that raised such a doubt, the text of the case was read, therefore, and 


\section{FIGURE 1: The LOC data and the historical path of judicial activism}

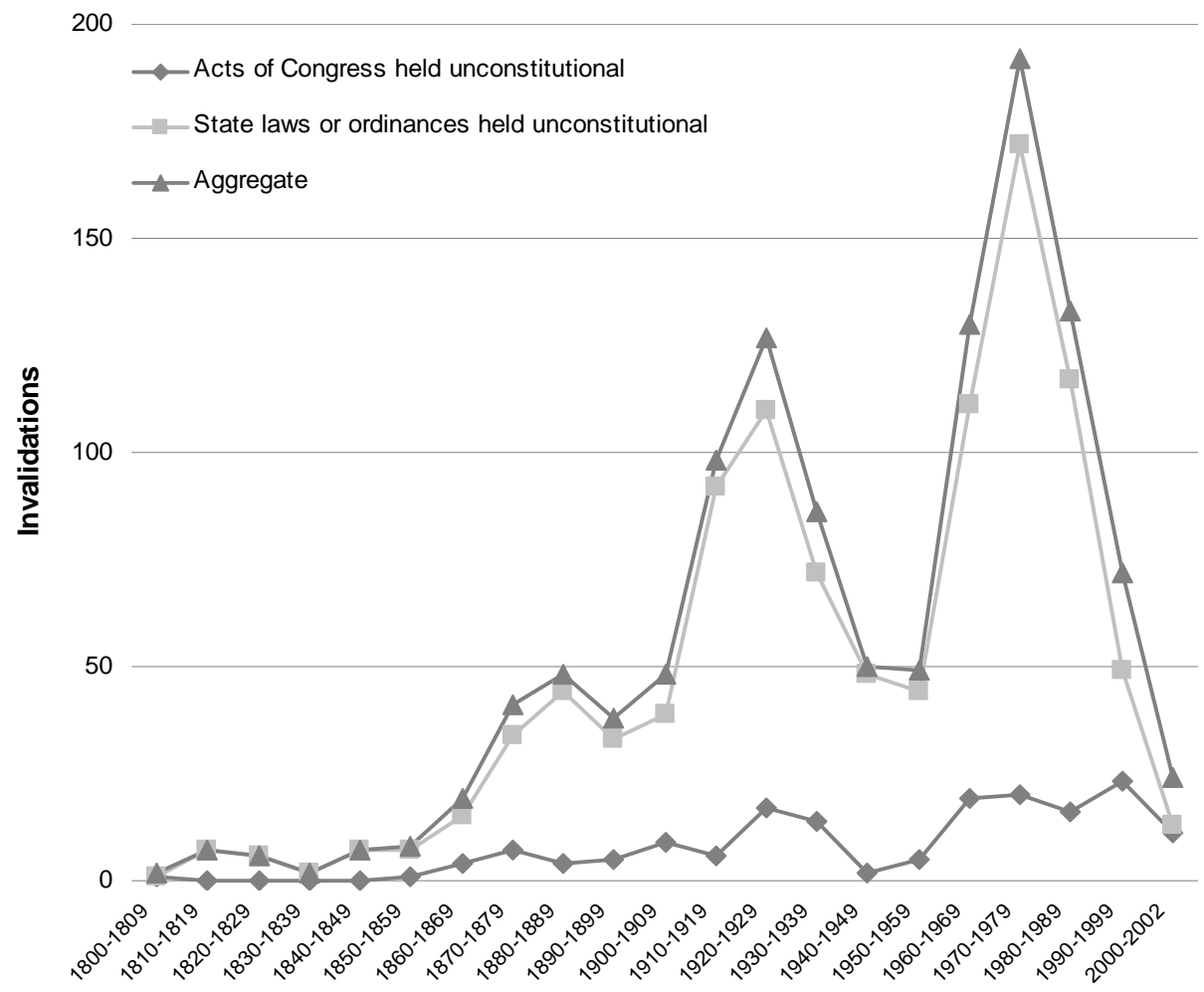

At first glance, the LOC data tell a familiar story. As Judge Posner explains, there is a sharp change at the beginning of the Warren Court. ${ }^{23}$ There is also a peak of judicial activity once Chief Justice Warren leaves the bench in 1969. It is followed, in the Rehnquist years, by a decline in the number of state and local laws being invalidated. In this more recent period, by contrast, invalidation rates have remained steady. Moreover, looking now at the decades immediately before the Warren Court, the beginning and end of the Lochner era are clearly discernible in the data.

All this is familiar fare. The surprising part of the story turns on what comes before the Lochner era. It is not the case that the Lochner era marks the

cases in which there was a separate constitutional ruling were added to the count of instances in which a state law was invalidated.

23. Posner, Rise and Fall, supra note 2, at 548. For one snapshot of that mid-twentieth century change, focusing on individual-rights cases alone, see Geoffrey R. Stone, O.T. 1983 and the Era of Aggressive Majoritarianism: A Court in Transition, 19 GA. L. REV. 15, 16-17 (1984) (focusing on the changing percentage of cases in which the Court rejected cases). Stone's analysis is incomplete insofar as it does not address the possibility that the Court's changing rate of rejection of individual-rights cases may be due to changes in the composition of the pool of cases before the Court (e.g., the Court's earlier activism has attracted outlier claims that the Court rejects). 
beginning of activism's ascent. The turning point in judicial behavior seems to come not as economic due process is on the rise in the late 1880s and early 1890s, but two decades earlier. The LOC's measure of judicial activism, which has been basically flat since the Republic's founding, suddenly takes off after the Civil War and during Reconstruction. Moreover, while the Warren Court can plausibly be described as a turning point, it can equally be read as simply a renewal of the trend line that began after the Civil War and that was merely temporarily suppressed after the death of economic due process. Self-restraint, on this view, died not in Little Rock, but sometime in the wake of Appomattox.

Notwithstanding the LOC's canonical status-or perhaps because of itthe federal data compilation has attracted strong criticism. It has recently been argued that the LOC data misses relevant antebellum judicial activity because its editors chose not to include as-applied invalidations of federal statutes or cases in which the Court simply declined to apply federal law on constitutional grounds. ${ }^{24}$ This omission results, some argue, in a significant undercount of judicial activism prior to the Civil War. ${ }^{25}$

To remedy this alleged defect, two political scientists, Tom S. Clark and Keith Whittington, have put together a challenger empirical study to the LOC data that is available online but has not been finalized in published form at the time of this writing. ${ }^{26}$ Rejecting the LOC list as "significantly underinclusive," Clark and Whittington offer their own list of 1260 cases in which the Supreme Court has either upheld or invalidated a federal statute on either as-applied or facial grounds. ${ }^{27}$ Like the LOC data, the version of the Clark-Whittington paper that was available online at the time of this writing does not contain a coding protocol that allows the study to be duplicated. ${ }^{28}$ This is, to be sure, a lacuna that the authors may well address in later versions of the paper (and I do not mean to suggest otherwise). Further, even though there are reasons for looking at the effect of judicial review on both state and federal laws, ${ }^{29}$ Clark and Whittington look only at cases involving federal statutes, although they usefully include in their count cases in which the Court upheld a federal law.

24. Whittington, Judicial Review Before the Civil War, supra note 18, at 1262.

25. Mark A. Graber, The New Fiction: Dred Scott and the Language of Judicial Authority, 82 CHI-KENT L. REV. 177, 181 (2007) (counting twenty pre-Civil War cases in which the Court imposed constitutional limits on congressional power). Graber argues that the antebellum Court was inclined to enforce constitutional norms in this indirect way, and that scholars have failed to notice this effect. Id.

26. Tom S. Clark \& Keith E. Whittington, Ideology, Partisanship, and Judicial Review of Acts of Congress, 1789-2006 (Working Paper, May 22, 2009), available at http://ssrn.com/abstract= 1475660.

27. Id. at 7.

28. For an introduction to the importance of creating replicable protocol, see LAWLESS ET AL., supra note 20, at 166-69. The Clark-Whittington paper contains a narrative description of the coding protocol that would be difficult or impossible to replicate. Clark \& Whittington, supra note 26.

29. See Frank B. Cross \& Stephanie A. Lindquist, The Scientific Study of Judicial Activism, 91 MINN. L. REV. 1752, 1770-73 (2007) (considering whether to include invalidations of state statutes and concluding there is no persuasive reason not to). 
The omission of federal judicial considerations of state rules raises questions about the validity of their results as comprehensive accountings of the federal bench's activism.

Putting aside these caveats there is one observation about the ClarkWhittington data worth stressing here. The trend line visible in the ClarkWhittington data (which I do not reproduce here ${ }^{30}$ ) has striking similarities to the LOC trend line. ${ }^{31}$ Of particular relevance to the argument to be developed in Part II, the Clark-Whittington data, just like the LOC data, suggest that the notable change in judicial behavior came around the post-Civil War and Reconstruction period rather than later in the nineteenth century.

Other nonquantitative studies of nineteenth-century judicial behavior point in a similar direction. Mark Graber has found nearly two dozen antebellum cases limiting federal power on constitutional grounds, but still concludes that there was no "judicial tradition, activist or restrained ... at the time when Dred Scott was decided [in 1857]." ${ }^{32}$ Rather, the case broke new ground, Graber argues, by employing for the first time language of constitutional invalidity in reference to a federal statute. ${ }^{33}$ Howard Gillman has emphasized the institutional transformation of the federal courts in the second half of the nineteenth century. From an "understaffed and unpaid" judicial infrastructure headed by justices perennially distracted by the travails of riding circuit, the federal courts had "become by century's end a real third branch of government." ${ }^{34}$ Further, Gillman emphasizes, new legislation expanding removal authority and adding federal question jurisdiction dramatically increased the reach and workload of the federal bench. ${ }^{35}$ In short, nonquantitative and historical studies isolate a shift in both federal judicial behavior and capacities around the end of the Civil War and the beginning of Reconstruction - that is, the very moment at which the LOC and ClarkWhittington data suggest was pivotal in the development of judicial activism.

\section{B. Limitations in the Data}

Yet both the LOC and the Clark-Whittington data have serious conceptual problems. Proceeding further without setting out those problems would be irresponsible. This Section therefore identifies five limitations to the data so far canvassed. To be clear, these problems imply there is some distance to go before our understanding of historical patterns of judicial activism can be taken

30. Because the Clark-Whittington paper is a draft, it seems inappropriate and presumptuous to reproduce their preliminary results here. Readers are, of course, encouraged to review the paper directly.

31. See Clark \& Whittington, supra note 26, at 11 (showing trends from 1789-2006).

32. Graber, supra note 25, at 180.

33. Id. at 181.

34. Howard Gillman, How Political Parties Can Use the Courts to Advance Their Agendas: Federal Courts in the United States, 1875-1891, 96 AM. POL. SCI. REV. 511, 512 (2002).

35. Id. at 515-17, 520. 
as robust. Nevertheless, as developed in Part II, I believe at least some inferences can be drawn from the LOC and Clark-Whittington data along with other sources, particularly where divergent methods yield similar conclusions. The five concerns grouped here, though, should be taken as threshold reasons for caution about the empirical foundations of the arguments to be developed in Part II as well as issues to be addressed in future research.

First, the LOC and the Clark-Whittington data do not trace precisely the same trajectory. The LOC data evinces less volatility than the ClarkWhittington data. This difference hints at consequential disputes about how best to count cases of judicial invalidation. For instance, in 1800, the Supreme Court held that a suit between two aliens could not proceed under section 11 of the 1789 Judiciary Act, notwithstanding the plain language of the statute, because such suits were not allowed under Article III of the Constitution. ${ }^{36}$ Does that count as the "invalidation" of a statute or is it an act of "narrowing" by statutory interpretation? ${ }^{37}$ Reasonable people can disagree. There is today a wide array of statutory interpretation tools that allow judges to apply constitutional norms short of making an explicit finding of invalidity. ${ }^{38}$ It has long been clear, for example, that the constitutional avoidance canon has both full-throated and more modest formulations. ${ }^{39}$ What lawyers or judges count as "invalidation" on constitutional terms will be endogenous to evolving conceptions of judicial craft. Reasonable people circa 1800 may therefore disagree about the proper categorization of a particular case to a different degree and on different terms from reasonable people in 2012. For example, decisions shaving off the most significant applications of a statute for constitutionally inspired reasons, but leaving the statute standing, might be seen as a more telling show of judicial power than other decisions explicitly resting on constitutional turf. ${ }^{40}$ For these reasons, it may not always be clear where the line between statutory interpretation and constitutional judgment should lie

36. Mossman v. Higginson, 4 U.S. (4 Dall.) 12 (1800).

37. Narrowing, of course, can be as objectionable as invalidation from Congress's perspective. See Frederick Schauer, Ashwander Revisited, 1995 SUP. CT. REV. 71, 95 ("[T] between a constitutionally inspired rewriting and an invalidation turns out to be illusory.”).

38. See, e.g., Edward J. DeBartolo Corp. v. Fla. Gulf Coast Bldg. \& Constr. Trades Council, 485 U.S. 568, 575 (1988) (citing NLRB v. Catholic Bishop of Chi., 440 U.S. 490, 499-501, 504 (1979)) ("[W]here an otherwise acceptable construction of a statute would raise serious constitutional problems, the Court will construe the statute to avoid such problems unless such construction is plainly contrary to the intent of Congress.").

39. See Adrian Vermeule, Saving Constructions, 85 GEO. L.J. 1945, 1949 (1997) (distinguishing modern from classical avoidance).

40. See, e.g., Schauer, supra note 37, at 95. Moreover, the Court can affirm a government action and in so doing suggest or confirm the breadth of judicial power. This was a tactic used seriatim by Chief Justice John Marshall. See Mark A. Graber, Establishing Judicial Review? Schooner Peggy and the Early Marshall Court, 51 POL. RES. Q. 221, 224 (1998) (explaining how Marshall would "preserve judicial power by asserting its existence, thus establishing precedents for future use, while not actually attempting to challenge executive or legislative authority in any controversial way"). It is hard to imagine a simple quantitative methodology that would pick out such cases. 
even absent the operation of the avoidance canon. Even if it was clear how to draw this line, it is not obvious how that line could be applied to the diverse range of judicial texts produced over the centuries to draw meaningful conclusions.

Second, neither the LOC nor the Clark-Whittington list addresses the judicial treatment of executive actions. ${ }^{41}$ It is common knowledge that as a result of the post-New Deal regulatory state, judges interact as much or more with the products of agency deliberation as statutes. Should not the effect of federal judges' constitutional views upon agency rulings and actions also count in a tally of "judicial activism," especially at a time when the executive is often recognized as an almost coequal democratic policy maker with Congress? To take this step raises further questions of enumeration and method. Scholars still diverge on how constitutionally grounded canons of interpretation should interact with the otherwise applicable rule of deference to agency interpretations of statutes. ${ }^{42}$ Against that background disagreement, it would be necessary to develop a way of defining when judicial review of agency action becomes sufficiently constitutional in tenor to measure activism in this domain. It would also be necessary to develop a means to apply that distinction to cases on the ground.

Third, both the LOC and Clark-Whittington data have a missing denominator problem. If the frequency of judicial invalidations moves over time, such a change may indicate that judges' attitudes and behavior are springing and shifting over time. Or it may not. Changes in the rate of judicial invalidation may also reflect changes in the background volume of state and federal laws (and perhaps regulations) over time. As the statute books engorge, the task of judicial review grows correspondingly more onerous. Even keeping the size of the statute books constant, the volume of invalidation may still rise if Congress and state legislatures enact more unconstitutional statutes (or the executive begins to enforce more previously quiescent unconstitutional enactments). This might be so if the early Republic's Congresses more carefully considered constitutional questions than their contemporary Beltway successors. ${ }^{43}$ These two trends-relating to the volume of legislation and the proportion of legislation that is constitutional-may provide an alternative, nonjudicial explanation for changes in the data. Neither can be rejected merely based on a review of the LOC or the Clark-Whittington data.

41. See LINDQUIST \& CROSS, supra note 15, at 94-99 (examining this question at the level of individual Justices).

42. See Caleb Nelson, Statutory Interpretation and Decision Theory, 74 U. CHI. L. REV. 329, 347 (2007) (noting uncertainty). For a recent proposal counseling case-by-case analysis, see Kenneth A. Bamberger, Normative Canons in the Review of Administrative Policymaking, 118 YALE L.J. 64, 68 (2008).

43. For an account of the early Congress that lends credence to this thesis, see DAVID P. CURRIE, THE CONSTITUTION IN CONGRESS: THE FEDERALIST PERIOD 1789-1801 (1997). 
The question of what variables should be used to generate a measure of changing judicial behavior, in short, remains to be answered. The complexity of the question - not to mention the manner in which it implicates highly contested, normative judgments about the domain of constitutional valuesmay counsel for skepticism about any real judgment about activism beyond the crude "head count" approach I employ here. ${ }^{44}$ At the very least, it suggests the need to take inferences from any single data source with a grain of salt.

Fourth, both the LOC and the Clark-Whittington data are partial and so potentially misrepresentative because they concern only the Supreme Court. That tribunal is merely the tip of the American judicial infrastructure. The activities of lower federal courts and state courts are also relevant to any accounting of judicial activism for two reasons. First, they may supplement Supreme Court action by invalidating important enactments even in the absence of substantive higher court review. ${ }^{45}$ Second, lower federal courts and state tribunals may drag their heels when operationalizing Supreme Court directives, mitigating their practical effect. This would result in underenforcement of a constitutional norm and the continued survival of some at least notionally unconstitutional state or federal statutes or practices. The Supreme Court has limited capacity to mitigate this sort of agency slack. As Judge Posner has observed, the Court "can no longer control the lower courts by means of narrow case-by-case determinations [and] must perforce act legislatively." ${ }^{46}$ It is therefore unsafe to assume that a high court instruction will be carried out faithfully by the diverse membership of state and lower federal judiciaries. ${ }^{47}$

Finally, judicial invalidations may differ in their size. A Court that invalidates a dozen trivial pensions and benefits provisions per year can plausibly be described as less "activist" than a court that invalidates one major federal statute annually. Not every case is Brown v. Board of Education. ${ }^{48}$ And, indeed, even the standalone effect of Brown, independent of the larger civil rights movement, has been subject to debate. ${ }^{49}$ There is thus both variance in and disagreement about the effect of decisions on the ground. Neither the LOC nor the Clark-Whittington data account in any fashion for the magnitude of a decision. ${ }^{50}$ The Clark-Whittington decision to omit state law invalidations

44. Cf. Easterbrook, supra note 4, at 1410 (expressing doubt that "an objecitve definition of activism ... [can] capture much of value").

45. E.g., Am. Booksellers Ass'n v. Hudnut, 771 F.2d 323 (7th Cir. 1985) (invalidating Indianapolis pornography statute), aff'd mem., 475 U.S. 1001 (1986).

46. POSNER, HOW JUDGES THINK, supra note 4, at 269.

47. The problem is acute even in the federal judiciary because of the absence of coordination on method. See Adrian Vermeule, The Judiciary Is a They, Not an It: Interpretive Theory and the Fallacy of Division, 14 J. CONTEMP. LEGAL IsSUES 549, 559 (2005).

48. 347 U.S. 483 (1954).

49. See generally, e.g., Gerald D. ROSENBERG, THe Hollow Hope: CAN COURTS BRING ABOUT SOCIAL CHANGE? (1991) (presenting empirical evidence of weak effect of the Warren Court's desegregation decisions).

50. See Cross \& Lindquist, supra note 29, at 1772-73 (noting the magnitude-of-decision 
further obscures matters. One might think a historical account of judicial review omitting Brown is somewhat incomplete. The footprint of decisions may also interact with the timing of a decision. It is plausible to posit that early judicial interventions, because they serve as dispositive precedent for longer periods of time, are systematically more important in setting the terms of institutional and doctrinal development than later cases. ${ }^{51}$ On this logic, the size of a judicial decision should also include a discount rate for its dwindling temporal proximity to the foundational moments of American history.

Even setting aside problems of verification and replication caused by the absence of coding information, the LOC and Clark-Whittington data provide mere snapshots of the whole. And they tell us nothing about when and how judicial activism has mattered to the democratic public, let alone to those segments of the public (such as women and African Americans) who were historically locked out of the polity and who might be expected to look with special fervor to the courts, rather than the political branches, for policy change. Yet such public sentiments may be salient to an evaluation of how countermajoritarian the exercise of judicial review in fact is. Both the LOC and Clark-Whittington data await amplification and clarification both by empirically and theoretically inclined scholars who will resolve the underlying conceptual issues and also the nettlesome problem of operationalizing those concepts in a way that enables "clear and detailed definitio[n]" of judicial activism. $^{52}$

These five analytic and conceptual shortfalls in the canonical data together suggest that we are presently some ways from an accurate estimate of the historical path of judicial activism across American history (if such a count is even possible). The denominator problem (number three) seems particularly hard to me. Any inferences from this data-of the kind essayed below-must therefore be sensitive to the absence of information about the magnitude of decisions' effects (numbers three and five), cautious about the effect of the regulatory state (number two), and attuned to volatility caused by counting errors (numbers one and four). Such inferences will perforce be modest, touching on only large themes, and not details, in the history of federal judicial review.

\section{Suggestions to Clarify the Historical Role of Judicial Activism}

The limitations of the standard data should have already sparked a rush to find new ways of relating the history of judicial activism. Indeed, it is remarkable and perhaps even embarrassing that the central practice of

problem in a general sense).

51. As an example of path-dependency-inducing jurisprudence, consider McCulloch $v$. Maryland, 17 U.S. (4 Wheat.) 316 (1819).

52. See LAWLESS ET AL., supra note 20, at 173 ("[R] egardless of the type of variable at issue, it is important that the researcher specify clear and detailed definitions of each variable ....”). 
constitutional law-the judicial act of invalidating laws based on their inconsistency with the Constitution-is so shrouded in empirical doubt. In that spirit, I briefly offer here two speculative suggestions about how the historical role of judicial activism might be clarified further. Neither completely answers the five critiques summarized above, but then neither is intended to do so. Both instead do provide some comfort for the project of making general inferences about the historical trajectory of judicial activism.

The first approach examines the temporal space between ratification/enactment of constitutional text and judicial review, building on work by Professor Adam Samaha. This approach queries how the introduction of new constitutional provisions affects the activism of the Court by providing new textual bases with which to invalidate statutes. Samaha noticed there is often a lag between the time a constitutional amendment is ratified and the time the Court first interprets the resulting new text. ${ }^{53}$ This gap between ratification and what we might call "first contact" averages forty years. ${ }^{54}$

A collateral benefit of using Samaha's data on the time lag between ratification and judicial interpretation of constitutional amendments is that doing so allows for the construction of a historical distribution of "first contact" points between the Court and constitutional text. This is arguably another snapshot into the timing of textual and doctrinal innovation by the Court, albeit a highly partial one. ${ }^{55}$ That is, the Samaha data tracks when the Court has turned to new constitutional text as grounds for considering (although not necessarily invalidating) laws on the basis of an individual right (although not on the basis of the original seven Articles). ${ }^{56}$ It shows the distribution of a particular (and surely quite limited) element of what might be termed judicial activism by charting when the Court has expanded the textual foundation upon which federal or state laws may be invalidated.

53. Adam M. Samaha, Originalism's Expiration Date, 30 CARDOZO L. REV. 1295, 1297 (2008).

54. Id. at 1310. Professor Samaha distinguishes interpretations from mere citations. Id. at 1365. He also reports that his definition of an "interpretation" is "liberal[]." Id. at 1310.

55. Id. at 1365. Alternatively, the Samaha data might measure a sort of judicial conservatismthe reliance on text rather than free-form reasoning to reach conclusions.

56. Id. at 1309. 


\section{FIGURE 2: The Samaha data on "first judicial contacts" for constitutional amendments}

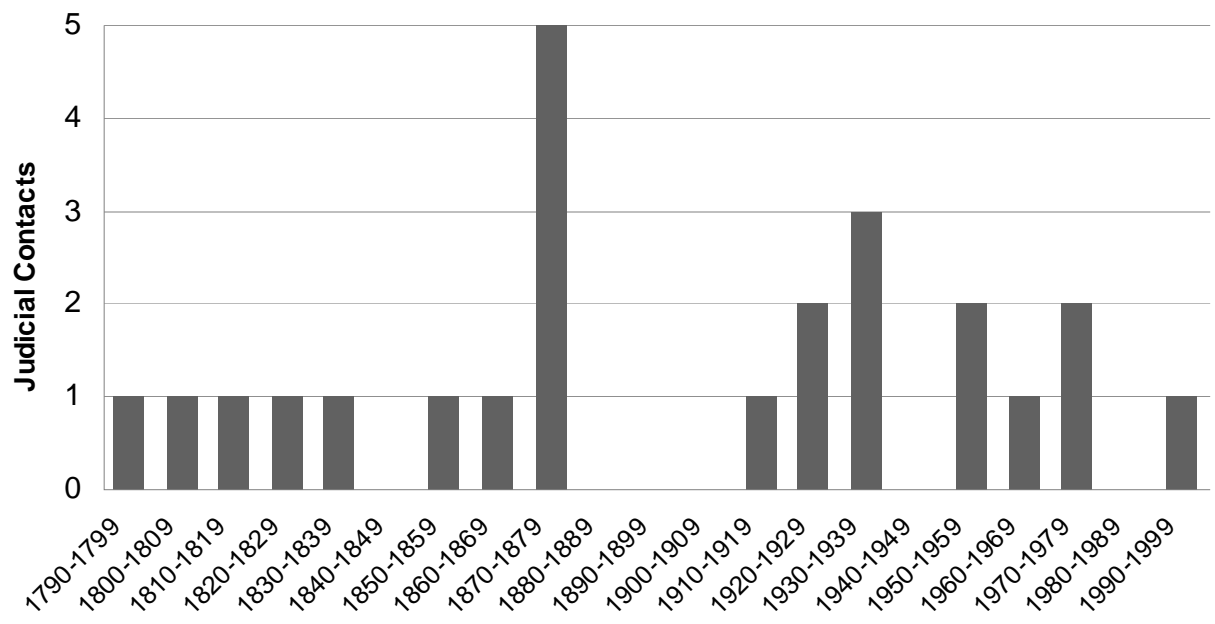

Notice, again, the sharp rise in the number of "first contact" points after the Civil War. There are easily discernible historical reasons for this spike in the data, most of which center on the Court's encounters with Reconstruction Amendments it could not have addressed previously. But however we explain that peak, the data lend more confidence to the inference developed in Part II: something happened to judicial behavior in the post-Civil War and Reconstruction period. For if three measures as distinct and different as the LOC data, the Clark-Whittington data, and the Samaha data each converge on that period in time as significant, this may be more than mere coincidence.

The second approach to the "when" of judicial activism is even more unorthodox. It does not even measure judicial behavior. Rather than ask what courts do, it asks when judicial activism comes to be a subject of public concern. That is, one can try to estimate changing public perceptions of the Court's behavior so as to draw a judgment about when members of the public started to categorize the actions of courts as activist. Public perceptions of activism are surely a highly imperfect proxy for judicial behavior. Although it is not implausible to think that changes in judicial behavior might lead to shifts in public opinion, it is also possible to imagine a diversity of exogenous causes of such shifts, ranging from changing economic conditions to the publicity efforts of ambitious elected officials, legislators, and candidates. ${ }^{57}$

57. As indeed appears to be the case in the 2012 presidential campaign. See Adam Liptak \& Michael D. Shear, Republicans Turn Judicial Power into a Campaign Issue, N.Y. TIMES, Oct. 23, 2011, http://www.nytimes.com/2011/10/24/us/politics/republicans-turn-judicial-power-into-acampaign-issue.html. 
One way to gauge the shift in public perceptions of judicial activism over time is to examine published works that address judicial actions. Google has now digitized 12 percent of all books (but, alas, not periodicals). ${ }^{58}$ In recent years, Google has enabled searches for the usage of an " $n$-gram," a string of letters separated by a given number of spaces, across time in the corpus. ${ }^{59}$ Using this search provides a glimpse less into the ebb and flow of daily discourse and more into patterns of sustained changes in general and scholarly debate. Two n-grams for "judicial activism" and "judicial restraint" are reproduced below.

FIGURE 3: Google n-grams for "judicial activism" and "judicial restraint"

a. n-gram for "judicial activism” (American English, 1800-2000, smoothing = 3)

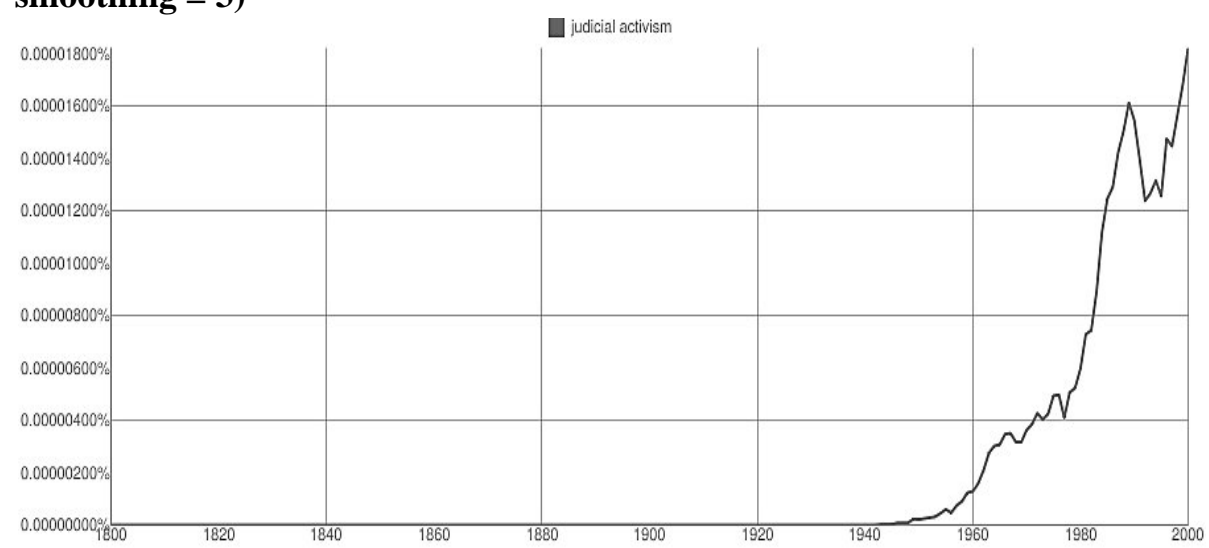

b. n-gram for "judicial restraint” (American English, 1800-2000, smoothing = 3)

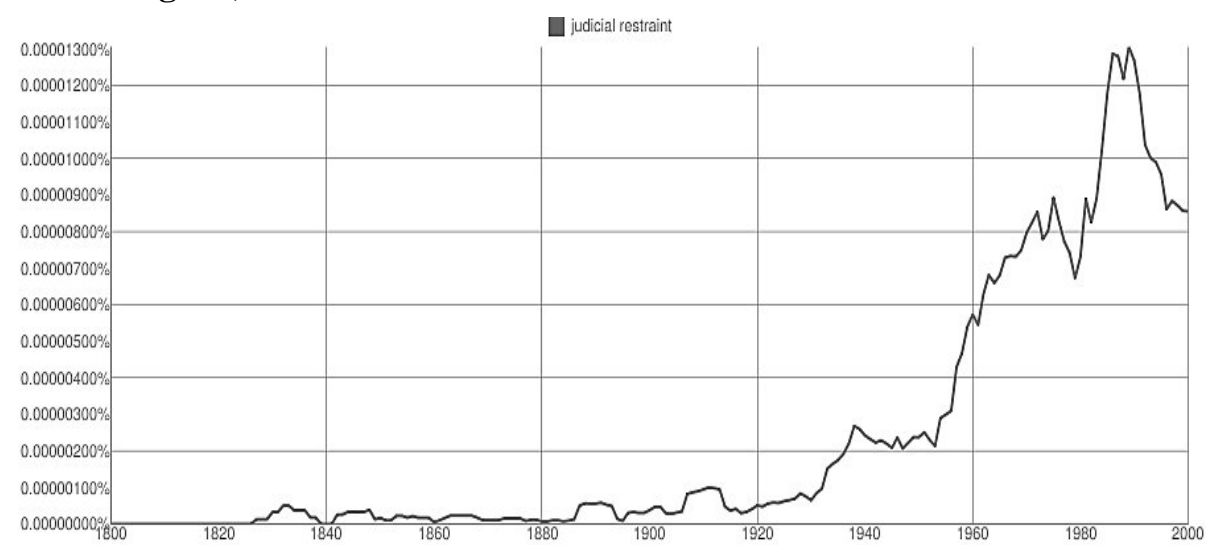

58. See Jean-Baptiste Michel et al., Qualitative Analysis of Culture Using Millions of Digitized 
Even as a measure of public attention to judicial activism, this snapshot is incomplete. ${ }^{60}$ The term "judicial activism" was allegedly coined only in January $1947 .{ }^{61}$ Yet as Judge Posner's genealogy shows, the basic substantive debates about constitutional invalidation go back much further in time. The term "judicial activism” may have had precursors not captured in these $n$-gram searches. What the $n$-grams may be capturing are the arcs of popular verbal formulations within current debates about judicial behavior. To the extent these primitive inquiries demonstrate the rise of a particular cultural understanding of activism, they are consistent with the thesis that Thayer's turn-of-the-century writing about judicial restraint had a lingering effect on broader debates. They also suggest that its disfavored sibling, judicial activism, did not appear in the public discourse with any frequency until more than a decade after its coining, around the end of the Warren Court in the 1960s. These data points do not prove that "the growing perception of the Court itself as a 'political' institution" was due to the "many politically divisive issues the Court has confronted since 1954." ${ }^{2}$ Rather, the time lag between the beginning of the Warren Court and the public's newfound focus on judicial activism suggests other forces beyond mere public observation of judicial behavior helped mobilize the public's interest, support, and outrage.

To summarize, available data about patterns of judicial activism across time are incomplete. My proposed supplements hardly complete the picture because they do not address the denominator question or supply a coding protocol for identifying what counts as the Court invalidating a law on constitutional grounds. Our understanding of judicial activism's historical path is, therefore, in need of much more extensive reconstruction. Nonetheless, both the standard sources of data and the two additional perspectives I have explored here suggest that the Warren Court may be less of a watershed of judicial behavior than generally believed. Instead, the Warren Court may rather be a turning point for the public's perceptions of that behavior, rather than judicial behavior itself. Those seeking to unlock the reasons why judicial activism arose would do better to begin their examination in the 1860s and 1870s. It is to those possibilities that I now turn.

Books, 331 SCIENCE 176, 176 (2011).

59. Id.

60. For data from newspapers that run from 1986 to 2005, see LINDQUIST \& CROSS, supra note 15 , at $11-12$.

61. The term is attributed to Arthur Schlesinger, Jr., from a Fortune magazine piece. Craig Green, An Intellectual History of Judicial Activism, 58 EMORY L.J. 1195, 1200 (2009).

62. Geoffrey Stone, Understanding Supreme Court Confirmations, 2010 SuP. CT. REV. 381, 443-44. The first time the phrase "judicial activism" was used in a judicial opinion appears to be in Theriot v. Mercer, 262 F.2d 754, 760 n.5 (5th Cir. 1959). 
II.

\section{RECASTING THE HISTORY OF JUDICIAL ACTIVISM}

What implications does our fragile contemporary knowledge about activism's history have for Judge Posner's argument? To rely on that data today is to make oneself hostage to tomorrow's scholarly insights, so I will do so very cautiously. I focus on one common hypothesis that can be supported with data from three of the approaches to judicial activism's history discussed above: judicial activism began in the post-Civil War and Reconstruction period, rather than during the heyday of the Warren Court.

\section{A. The Warren Court}

Judge Posner identifies the "exuberant" Warren Court as a turning point in the historical ascension of judicial activism and also as the beginning of a ratchet effect on judicial incentives to engage in some freewheeling kind of activism. ${ }^{63}$ This is a familiar trope in the academy. The Warren Court has long been alternately celebrated or trashed for its criminal procedure and equality rulings. ${ }^{64}$

At first blush, both the LOC and the Clark-Whittington data seem to confirm Posner's assertion that the Warren Court inaugurated today's judicial activism. The rate of judicial invalidations by the Supreme Court was indeed on the decline around World War II, surely reflecting the Justices' abandonment of economic due process. Only in the late 1950s did the rate of judicial invalidations start to manifest.

But from another perspective, the Warren Court represents a return to a judicial form familiar since the Civil War's wake. The LOC, ClarkWhittington, and Samaha data all point toward a period after the Civil War and during Reconstruction as a pivotal moment in patterns of judicial behavior. The trend line of raw judicial invalidations, roughly flat since the beginning of the Republic, changes direction at this time. It assumes an upward gradient that continues, with some interruptions, almost up to the present day. As noted in Part I, this postbellum change in judicial behavior also coincides with shifts identified by Graber and Gillman in the rhetoric of judicial decisions and the institutional infrastructure of the federal courts. ${ }^{65}$ Hence, one could draw a trend line straight back through the Warren Court and the Lochner-era precedent to reach the first inklings of activism at the close of the Civil War.

On this view, what calls for explanation is less the Warren Court as an innovator, and more the gap between the antebellum Court of the 1850s and the postbellum Court of the 1860s and 1870s. ${ }^{66}$ From this second perspective,

63. Posner, Rise and Fall, supra note 2, at 546.

64. LINDQUIST \& CROSS, supra note 15, at 3-5.

65. See supra text accompanying notes 32 to 35 .

66. It is also worth asking how the later transitions from one temporarily popular sort of judicial 
Judge Posner might be right to talk of a "rise and fall," but might do well to redraw the temporal scope of the claim. One might also wish to speak not of a unipeaked rise of judicial activism, but rather to view the history of judicial activism as a sequence of epicycles within a larger historical movement, with relatively aggressive and restrained moments alternating over time. Within the decline of judicial self-restraint, that is, it may be possible to chart tidal ebbs and flows in judicial behavior.

If it is indeed the 1860s and 1870s — not the 1950s - that are the most important pivot in judicial activism, we must reexamine Posner's claim that the post-Warren conservative Justices were forced to adopt an activist stance because they "were not about to embrace the ratchet theory of judicial restraint." 67 The "ratchet" theory that Posner is intuiting here rests on the claim that once one political coalition has stacked the courts with its allies, turning the federal judiciary to its transient programmatic and policy ends, there is no incentive for opposing political coalitions to disarm unilaterally by refraining from the same strategy when they are elected into national office. If it has force, this ratchet theory should not be limited to explanations of the efflorescence of conservative judicial activism in the 1970s and 1980s. It may also cast light on the Warren Court's exploitation of footnote four of Carolene Products $^{68}$ as a warrant for robust activism on behalf of socially vulnerable and politically marginalized minorities. That is, in making judicial appointments, the political coalitions responsible for creating the Warren Court were also responding to an empty space for judicial activism left by the defeat of the conservative Lochner Court. ${ }^{69}$ And the ratchet theory can be extended back even further to the Lochner era itself. ${ }^{70}$ Perhaps, that is, the rise of economic due process itself can be explained as a response to earlier forms of judicial activism. On this account, judicial activism was hardwired into the American constitutional system long before Earl Warren came to the Court, and the ratcheting up of activism cannot be laid at the doors of the 1950s and 1960s

activism (e.g., economic due process) to another (e.g., due process) were accomplished. For example, a focus upon the Warren Court alone might elide the important political work done by Roosevelt's Justice Department previously both in pressing Reconstruction-era statutes and in screening judicial nominees for their views on race. See KEVIN MCMAHON, RECONSIDERING ROOSEVELT ON RACE 138, 150-75 (2004). In this context, the Warren Court is even less countermajoritarian, and even more a conscious product of national political actors' calculated expenditures, than is generally thought. Further, this project began long before Warren himself joined the Court.

67. Posner, Rise and Fall, supra note 2, at 547.

68. United States v. Carolene Prods. Co., 304 U.S. 144, 153 n.4 (1938); see also KECK, supra note 10, at 29 (arguing for the historical significance of footnote four).

69. See KECK, supra note 10, at 93 ("[W]hile the [Warren Court] justices were motivated in part by jurisprudential concerns, they were also seeking to promote the political values of the New Deal/Great Society coalition, of which they themselves were enthusiastic members.”).

70. See Mark A. Graber, Constructing Judicial Review, 85 AnN. REV. POL. SCI. 425, 435 (2005) ("The Taft, Harding, and Coolidge administrations fought to staff the federal judiciary with political actors prone to construe ambiguous Constitutional and statutory language against labor.”). 
Court. ${ }^{71}$ Further, if judicial activism does have deeper roots in American history, it follows that the Warren Court was less of a countermajoritarian trailblazer than commonly believed. ${ }^{72}$ Rather, an older iteration of the Supreme Court whose political salience has dimmed into obscurity is really the crucible in which judicial activism was birthed.

\section{B. The Postbellum Period}

So it may be that the true inception of judicial activism was at the end of the Civil War, not the opening of the Civil Rights era. But with fleeting exceptions, this moment in American history has not been identified as seminal for the phenomenon of judicial review. ${ }^{73}$ Some attention to the case law of the time, however, may cast new light on how judicial activism first got off the ground.

As an initial matter, the postbellum period is often thought of as a time at which the Court found itself at odds with a national political coalition through its close superintendence of Reconstruction law enforcement, paper money laws, and civil rights measures. ${ }^{74}$ One result of this confrontation, as Lucas Powe has observed, was eleven postbellum invalidations of federal statutes in a period of less than two decades - a stark contrast with a far lower invalidation rate before the war. ${ }^{75}$ Attention to the pattern of federal law invalidations indeed suggests that the postbellum Court was at best indifferent to the goals of Reconstruction. The postwar Court invalidated both pro-Reconstruction civil rights efforts and legislation enacted to address President Andrew Johnson's

71. Cf. Keith E. Whittington, "Interpose Your Friendly Hand": Political Supports for the Exercise of Judicial Review by the United States Supreme Court, 99 AM. POL. SCI. REV. 583, 586 (2005) (hereinafter Whittington, "Interpose Your Friendly Hand") (arguing that the Marshall Court "won the approval of national officials by imposing their shared constitutional agenda on recalcitrant state actors who hamper[ed] national political goals").

72. See, e.g., Corinna Barrett Lain, Countermajoritarian Hero or Zero? Rethinking the Warren Court's Role in the Criminal Procedure Revolution, 152 U. PA. L. REV. 1361 (2004); Whittington, "Interpose Your Friendly Hand," supra note 71, at 587.

73. One exception is a penetrating article by Howard Gillman, which observes in passing that the Court "began after the Civil War to strike down laws with greater regularity and to involve itself in more significant national policy disputes." Gillman, supra note 34, at 512 (citations omitted).

74. Recall that the Court's threat to invalidate military reconstruction under the rule of Ex parte Milligan, 71 U.S. (4 Wall.) 277 (1866), was serious enough to prompt Congress to cut off Supreme Court jurisdiction. See Ex parte McCardle, 74 U.S. (7 Wall.) 506 (1869). The Court briefly invalidated the use of paper money necessitated by war debts. Kenneth W. Dam, The Legal Tender Cases, 1981 SUP. CT. REV. 367. It then freed the perpetrators of the Colfax Massacre. United States v. Cruikshank, 92 U.S. 542 (1876). And the Civil Rights Act of 1875, which to be sure had been already stripped of prescriptive components, denounced in the press, and sidelined by President Grant, received a frosty welcome. The Civil Rights Cases, 109 U.S. 3 (1883). Recent scholarship, however, argues that the Civil Rights Cases, in particular, had much less impact on federal enforcement authority than is commonly believed. See Pamela Brandwein, A Judicial Abandonment of Blacks? Rethinking the "State Action" Cases of the Waite Court, 41 LAW \& SOC'Y REV. 343, 347 (2007) (arguing that "state action doctrine was not a definitive or wholesale abandonment of blacks to their former masters").

75. POWE, supra note 9, at 144 . 
use of the pardon power to draw back in former Confederate supporters. ${ }^{76}$ So one inference from this pattern of invalidations is that the post-Civil War era was characterized in part by a conflict between a fragment of an antebellum ancien régime clinging onto power in the Supreme Court (where the Radical Republicans never appointed a majority of the Justices), and the Reconstruction Congress itself during a brief window of vigorous legislative action in favor of Southern blacks. ${ }^{77}$ Slow turnover on the Court, impeded by the tempestuous relationship between President Johnson and the Congress, meant that wholehearted judicial laboring on behalf of Reconstruction aims was never likely in the first place. ${ }^{78}$ At best, Michael Les Benedict has argued, the Court instead remained bound to an ideology of "State-centered nationalism" that constrained its willingness to act vigorously in favor of racial equality. ${ }^{79}$

Patterns of judicial action respecting federal laws, however, are only part of the story about judicial activism in this era. The LOC data contain eleven cases between 1860 and 1879 in which federal laws were invalidated, and forty-nine cases in which state enactments were invalidated. The larger part of the story of judicial activism in the postbellum era thus concerns the judicial treatment of state statutes. But this part of the historical story is poorly understood. Historical attention to the era has tended to focus on the Civil War as a freestanding "constitutional crisis," rather than examining the shifting pattern of judicial behavior in the pre- and postbellum eras. ${ }^{80}$ The habitual periodization in the era's historiography, for instance in the Holmes Devise, also conduces to inattention about the transitional nature of the Civil War and the rupture between the ante- and postbellum Courts. ${ }^{81}$ And much of the

76. For examples of civil rights remedies being curtailed, see United States v. Harris, 106 U.S. 629 (1883) (declaring federal penalization of certain crimes unconstitutional), and United States $v$. Reese, 92 U.S. 214 (1876) (upholding discriminatory voting practices). For the pardon cases, see, for example, United States v. Klein, 80 U.S. (13 Wall.) 128 (1871), and Ex parte Garland, 71 U.S. (4 Wall.) 333 (1867). The conflict should not be overstated. At the same time that the Congress was coming into conflict with the Court in these cases, it was also expanding federal court jurisdiction to effectuate federal policies in the South. KeITH E. WhitTingtON, POLITICAL FOUNDATIONS OF JUDICIAL SUPREMACY: THE PRESIDENCY, THE SUPREME COURT, AND CONSTITUTIONAL LEADERSHIP IN U.S. HISTORY 114-15 (2007).

77. Interestingly, Stephen Skowronek's history of presidential politics as a series of conflicts between shifting regimes identifies the Johnson presidency as one of particularly sharp conflict, wherein the President "provoked major constitutional crises over the legitimate exercise of presidential power.” STEPHEN SKOWRONEK, THE POLITICS PRESIDENTS MAKE: LEADERSHIP FROM JOHN ADAMS TO BILl CLINTON 44, 450-51 (1997).

78. See WhitTington, supra note 76, at 212-13.

79. Michael Les Benedict, Preserving Federalism: Reconstruction and the Waite Court, 1978 SuP. CT. REV. 39, 56. Les Benedict's argument aims to explain the narrow holding of the SlaughterHouse Cases, and does not try to account for the observed rise in invalidations on other grounds. Id. at 57-61.

80. See Arthur Bestor, The American Civil War as a Constitutional Crisis, 69 AM. HIST. REV. 327 (1964). I am grateful to Alison LaCroix for her insight into the historiography of the period.

81. See Daniel W. Hamilton, Popular Constitutionalism in the Civil War: A Trial Run, 81 CHI.KENT L. REV. 953, 955 (2006) (criticizing the Holmes Devise on this point). 
literature on the postbellum period has (albeit for good reason) focused on the fate of federal projects such as Reconstruction. ${ }^{82}$ The question of why so many more state statutes were invalidated after the war has not been so carefully examined.

Different hypotheses might explain the changing judicial treatment of state laws in the postbellum period. An obvious threshold hypothesis would be that the Reconstruction Amendments provided the courts with a textual invitation to impose new kinds of constraints upon the states, one that courts eagerly took up. This interpretation may seem at first to be consistent with the Samaha data. But other data suggest it is unlikely to carry much weight. Consider for a moment some details of the changing pattern of state law invalidations after the Civil War. The first postwar invalidation of a state law on the basis of one of the Reconstruction Amendments is Strauder v. West Virginia $^{83}$ in 1880. Between the end of the war and the ratification of the first Reconstruction Amendment in December 1865 and Strauder's being handed down in 1880, the LOC data show forty-four other state laws being invalidated on the basis of a conflict with a provision of the antebellum Constitution. After Strauder, a decade passes before another law was invalidated on Reconstruction Amendment grounds-this time on a theory of economic due process. ${ }^{84}$ In the intervening decade, thirty-three other opinions were issued in which the Court invalidated state laws without citing the Reconstruction Amendments. That is, judicial behavior may have changed after the Civil War, but this change cannot be attributed to the Reconstruction Amendments. Indeed, since most Southern states were under the thumb of Reconstruction administrations through some point in the 1870s, an absence of state laws' being invalidated on such grounds is hardly surprising. ${ }^{85}$

If not due to the novelty of the Reconstruction Amendments, then what explains the new enforcement of the antebellum Constitution against the states? In the space of a brief essay, I can only offer a tentative hypothesis in response to this question. To this end, an examination of the forty-nine Supreme Court cases identified by the LOC between 1860 and 1879 in which a state statute was invalidated provides a launching point. A majority of those cases involve either interstate commerce or banking. Ten of the cases involved a railroad company as a litigant, while nine others involved a shipping company and still

82. For a recent example, see Jack M. Balkin, The Reconstruction Power, 85 N.Y.U. L. REV. 1801 (2010) (arguing that Supreme Court civil rights jurisprudence contradicts the text and history of the Thirteenth, Fourteenth, and Fifteenth Amendments, and exhorting Congress to more aggressively invoke powers under those Amendments).

83. 100 U.S. 303 (1880).

84. Chi., Milwaukee \& St. Paul Ry. v. Minnesota, 134 U.S. 418 (1890).

85. See ERIC FONER, RECONSTRUCTION: AMERICA's UNFINISHED REVOLUTION, 1863-1877, at 346-459 (2002). 
another nine involved banks. That is, what lies beneath this first wave of judicial activism is the rising tide of industrialization. ${ }^{86}$

In this light, the changing pattern of postbellum judicial behavior might be explained as the product of an interaction between two forces. First, economic historians have emphasized the way in which not only transportation companies such as railroads, but also corporations that manufactured goods for new internal consumer markets, such as the sewing machine manufacturer I.M. Singer \& Company, began expanding nationally through the 1860s and 1870s in ways that strained against "state trade barriers" and that aspired toward a national common market. ${ }^{87}$ Second, these corporations made their demands for expanded markets not only directly before the federal courts but also in the political sphere. Historians such as Howard Gillman have argued that the postbellum Republican Party was increasingly sympathetic to the plight of nascent national industries, and consequently made increased efforts to rework the federal judicial power through appointments and jurisdictional changes so the bench could "play an important role in promoting a policy of economic nationalism." ${ }^{88}$ Following the lead of earlier historians, Gillman has also emphasized the catalytic role of statutory changes to federal court jurisdiction in 1875, which opened those courts to a newly emerging class of national corporations. ${ }^{89}$ Even prior to that, a wave of Republican appointments also began reworking the rules for ascertaining the diversity of corporate litigation "to allow corporations to sue and be sued more easily in national courts."90

The net result of these forces was that I.M. Singer and the other corporate players with national ambitions could press their claims against state laws in federal courts" before judges "deeply influenced by the interests and ideologies that emerged during postbellum industrialization"92 and who were

86. For a recent survey of the historical period emphasizing changing economic trends, see generally H.W. BRANDS, AMERICAN COLOSSUS: THE TRIUMPH OF AMERICAN CAPITALISM 18651900 (2011).

87. Charles W. McCurdy, American Law and the Marketing Structure of the Large Corporation, 1875-1890, 38 J. ECON. HIST. 631, 637 (1978); see also TONY ALLAN FREYER, FORUMS OF ORDER: THE FEDERAL COURTS AND BUSINESS IN AMERICAN HISTORY, at xix, 102-03 (1979) ("Throughout the years following the Civil War, corporations doing interstate business faced the unhappy consequences of state law that frequently lacked uniformity and was often discriminatory.”). Why the I.M. Singer Company? Sewing machines are complex objects; they are best sold not by franchisees but through a nationwide sales force.

88. See Gillman, supra note 34, at 516.

89. Id. at 516-17; accord William M. Wiecek, The Reconstruction of Federal Judicial Power, 1863-1875, 13 AM. J. LEGAL HIST. 333, 333-34 (1969) (enumerating postbellum changes to federal jurisdiction and explaining their significance).

90. EDWARD A. PURCELl, JR., Litigation AND INEQUAlity: FEDERAL Diversity JURISDICTION IN INDUSTRIAL AMERICA, 1870-1958, at 17 (1992).

91. McCurdy, supra note 87, at 640-42; accord PURCELL, supra note 90, at 20 (noting the “growing corporate preference for the national courts [between] 1855 and 1885”).

92. Howard Gillman, Reconnecting the Modern Supreme Court to the Historical Evolution of American Capitalism, in THE SuPREME COURT IN AMERICAN POLITICS: NEW INSTITUTIONALIST INTERPRETATIONS 235, 237 (Howard Gillman \& Cornell Clayton eds., 1999). 
also willing to "ameliorate the uncertainties created by the diffuse pattern of state incorporation laws." 93 This convergence of political and economic forces thus may have conduced to a postwar uptick in invalidations. Judicial activism in its original state, in other words, may well be best read to be a side effect of economic nationalization. Rather than responding to regional outlying preferences over racial politics as the Warren Court did, judicial activism in its formative days was committed to economic libertarian ends-the construction and deepening of the emergent American common market.

Finally, there is an alternative, but not mutually exclusive, potential explanation for the postbellum change in judicial behavior that focuses on a different kind of learning by the federal bench. This argument would focus on the lesson that Dred Scott taught the federal bench. The aftermath of that case suggested that the federal courts could make dramatic inroads into the disposition of important national issues, and, even if the results thereof were morally or politically catastrophic, could survive with relatively scant longterm damage. Dred Scott thereby fostered awareness amongst federal judges of the bench's potential long-term stability and institutional durability. This in turn had a moral hazard effect. It made it cheaper for the Court to dabble in activism because the Justices knew that negative reputational consequences would evaporate with time. When called upon by national commercial interests and the reconfigured postwar Republican Party, federal judges were thus primed for action.

\section{Public Discussion of Judicial Activism}

The seminal role of the postbellum period in nurturing the judicial activism we know today raises a further, separate question: Why does the Warren Court loom so large in the current legal imagination? Judge Posner is not an outlier in finding significance in that more recent period. Indeed, it is now almost canonical to regard the Warren Court as a transition point in patterns of judicial behavior.

In answering this question, the shifting public usages of "judicial activism" may be relevant. The $n$-grams reproduced in Figure 3 suggest that the Warren Court did indeed mark a change-not in the way judges decided cases, but in the way the public discussed judicial behavior. Perhaps the speed and compression of legal change during the Warren era is salient here. ${ }^{94}$ It is also plausible that the Warren Court's importance lies in how it provided a generation of post-Goldwater politicians with a new platform to mobilize latent constituencies in a reconfigured and more ideologically homogeneous national party system. ${ }^{95}$ Under this theory, the Warren Court midwifed a new political

93. FREYER, supra note 87, at 110.

94. See Posner, Rise and Fall, supra note 2, at 548.

95. For one account of the effect of this political change on the law, see generally JONATHAN 
argument about "judicial activism," an argument that still captivates thinking about the federal judicial role even if that role did not change demonstrably during the Warren years. ${ }^{96}$ Perhaps this theory also captures the imagination of a public that increasingly views politicians as elite and antidemocratic, with notionally countermajoritarian courts serving as exemplars of a perceived democracy deficit. That view has stuck, notwithstanding dramatic changes in the Court's composition. The Warren Court, in short, matters less for what it was and more for how it distilled democratic resentment against perceived judicial and political elites.

Public anger at legal elites may have also captured the attention of a generation of legal scholars and judges who came of intellectual age with Justice Warren as an exemplar, whether positive or negative, of what a judge might be. ${ }^{97}$ As a result, the Warren Court precipitated a wave of "constitutional theory" aimed at supplying "right" answers to difficult constitutional questions. $^{98}$ This suggests-albeit without proving-that the rise of constitutional theory as a discipline is, while not necessarily causally related to judicial activism in the courts, still just a side effect of public and political debate about judicial activism.

Constitutional theory may have a separate connection to claims about judicial activism. To accuse a judge of judicial activism implies a benchmark of acceptable judicial behavior. To make that label into a pejorative accusation requires some sort of normative theory of constitutional review. Participants in that public debate need to be credentialed to expound on the "right" constitutional result. If that is so, theories of constitutional interpretation such as originalism may not matter only because they directly influence or correlate with outcomes in constitutional cases (if indeed they do matter to the outcomes of particular controversies). ${ }^{99}$ They may matter instead because they help construct and channel diffuse public judgments about when judicial action is warranted. In other words, constitutional theory supplies the normative benchmarks implicit in manifestly political claims about the appropriateness of judicial behavior. While the direct influence of individual scholars is often hard to discern, collectively scholars may thereby provide a significant resource for political argumentation. Like Tin Pan Alley songsmiths, legal scholars churn

SimON, GOVERNING THROUGH CRIME: HOW THE WAR ON CRIME TRANSFORMED AMERICAN DEMOCRACY AND CREATED A CULTURE OF FEAR (2007).

96. See, e.g., FREDERICK P. LEWIS, THE CONTEXT OF JUdiCIAL ACTIVISM: THE ENDURANCE OF THE WARREN COURT LEGACY IN A CONSERVATIVE AGE (1999).

97. See, e.g., JOHN HART ELY, DEMOCRACY AND DISTRUST: A THEORY OF JUDICIAL REVIEW, at $\mathrm{v}(1980)$.

98. Posner, Rise and Fall, supra note 2, at 546 (dating "rising intellectual ambition of legal academics" to roughly the 1960s).

99. As Judge Posner has observed, no such correlation exists. See PosNER, How JudGeS THINK, supra note 4, at 366 ("My impression is that politically like-minded judges usually vote the same way despite their different judicial philosophies.”). 
out a frothing tumult of ideas in the hope that one catches. ${ }^{100}$ Individually irrelevant, collectively they generate the volume and diversity of scholarly production to feed public debate about the Court. The social value of a piece of constitutional theory is therefore its option value as political rhetoric.

If then "the Roberts Court... bids fair to exemplify conservative activism" in full flower, ${ }^{101}$ this is surely a credit to conscious and durable intellectual investments in both the academy and the government. Those investments lent "cultural capital to be taken seriously in fields with deeply embedded expectations of participants' experience, knowledge, and cultural competence." ${ }^{102}$ They supplied intellectual oxygen to a generation of lawyers and judges to render not merely plausible, but inevitable, forms of judicial activism that would have been unthinkable mere years beforehand. ${ }^{103}$

\section{CONCLUSION}

Judge Posner's Essay on judicial activism and self-restraint raises many important points. Equally worthy of note is the manner in which it tees up novel and consequential questions about the historical trajectory of judicial behavior. Currently available data provide surprisingly thin responses. Far more work-both empirical and theoretical-seems to be warranted. In the interim, however, cautious speculation on the appropriate period for close historical scrutiny seems not just plausible but proper given the continued muddied public debate about the role of constitutional review in a democratic polity. Such speculation suggests that the Warren Court did not play the seminal role in changing the norms of judicial behavior that conventional wisdom has suggested. Instead, it points to an earlier period of centripetal nationalism after the Civil War as the truly transformative moment in the American story of judicial activism and self-restraint.

100. Publishing houses would purchase a handful of songs, and then lobby media, for example, with payola, to secure airplay. NichOlas E. TAWA, THE WAY to Tin PAN ALLEY: AMERICAN POPULAR SONG, 1866-1910, at 43 (1990).

101. Posner, Rise and Fall, supra note 2, at 551.

102. Steven M. Teles, The Rise of the Conservative Legal Movement: The Battle FOR CONTROL OF THE LAW 19 (2008). In charting the rise of the conservative legal movement that has its current acme in one branch of the Roberts Court, Teles underscores the pivotal role of intellectual investments. Id. at 73, 83, 163-67.

103. Consider the trajectory from Judge Bork's 1989 rejection of an individual Second Amendment right, to Justice Scalia's opinion in District of Columbia v. Heller, 554 U.S. 570 (2008). Compare Claudia Luther, Bork Says State Gun Laws Constitutional, L.A. TIMES, Mar. 15, 1989, at B5 (documenting Bork's position), with Reva B. Siegel, Dead or Alive: Originalism as Popular Constitutionalism in Heller, 122 HARV. L. REV. 191, 222-25 (2008) (discussing Heller). As Judge Posner points out, it is superficially mystifying why Justice Stevens, whom Posner describes as possessing "no discernible judicial philosophy, but leaning toward pragmatism," POSNER, HOW JUDGES THINK, supra note 4, at 346, would play on originalism turf, see Posner, Rise and Fall, supra note 2, at 549. But the ability of originalism to command the field of argument, even when a pragmatist is playing, is merely the return from the intellectual investments described by Teles in that constitutional methodology. 
